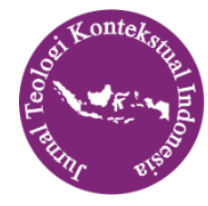

Jurnal Teologi Kontekstual Indonesia

ISSN 2722-8630 (online)

https://journal.sttsimpson.ac.id/index.php/JTKI/

Vol. 1, No. 2 (2020): 94-102

\title{
Budaya Honor Shame dalam Konteks Pelayanan pada Sebuah Gereja Kota di Bekasi
}

\author{
David Alexander Paksoal \\ Sekolah Tinggi Filsafat Jaffray Makassar \\ david.paksoal@gmail.com
}

\begin{abstract}
Culture is the ecosystem in which an indivdiual live and interact with its society. This ecosystem shapes the how individiual and community think, feel and behave. Ministry is one of the areas in life that is affected by culture. This paper will explain about the concept of culture and more specifically the honor shame culture. The purpose of this research is to know the influence of honor shame culutre in the ministry of Gereja Kemah Injil Indonesia Jemaat Rehobot Taman Wisma Asri Bekasi. This research will be using ethnography approach. Theoritical findings through literature study will be evaluated and descriptively explained according to the findings acquired in the field using observation and interview. According to this research, the conclusion is that the ministry of Gereja Kemah Injil Indonesia Jemaat Rehobot Taman Wisma Asri Bekasi is influenced by the honor shame culture.
\end{abstract}

Key words: Ministry, culture, honor shame, church

\begin{abstract}
Abstrak
Budaya merupakan suatu ekosistem di mana individu tinggal dan berinteraksi dengan lingkungan. Ekosistem ini memembentuk cara berpikir, bersikap dan berperilaku pribadi dan juga komunitas. Pelayanan merupakan salah satu bidang kehidupan yang juga terpengaruh dalam budaya. Untuk itu dalam tulisan ini akan dibahas mengenai konsep budaya secara umum dan secara khusus budaya honor shame. Tujuan dari penelitian ini adalah untuk mengetahui pengaruh dari budaya honor shame dalam pelayanan di Gereja Kemah Injil Indonesia Jemaat Rehobot Taman Wisma Asri Bekasi. Metode yang digunakan dalam penelitian ini adalah pendekatan ethnography. Temuan teoritis berdasarkan studi kepustakaan akan dibandingkan dan dijelaskan secara deskriptif lewat temuan di lapangan yang diperoleh melalui observasi dan wawancara. Berdasarkan penelitian dapat disimpulkan bahwa pelayanan dalam Gereja Kemah Injil Indonesia Jemaat Rehobot Taman Wisma Asri Bekasi, dipengaruhi oleh budaya honor shame.
\end{abstract}

Kata-kata Kunci: Pelayanan, budaya, hormat malu, honor shame, gereja

\section{Pendahuluan}

Ronald Muller, seorang misionaris injili menghabiskan waktu pelayananya di budaya Arab dan memperkirakan bahwa terdapat tiga jenis dalam semua budaya. Muller menyebut kan mengenai innocence-guilt, shame-honor dan fear-power. Kemudian dalam kebanyakan budaya akan menemukan dinamika ketiganya namun ada satu yang lebih dominan. ${ }^{1}$ Selanjutnya April dan Mooketsi memberikan pandangan tentang Shame dan Guilt menurut

${ }^{1}$ Roland Muller, Honor and Shame: Unlocking the Door, 1st edition. (Philadelphia, Pa.: Xlibris, 2001), 69; Aleya James and Candy McLeod, "An Analysis of the Three Colors Worldview Mapping Tool: Contrasting Emirati and Non-Emirati Worldviews," Intercultural Communication Studies XXIII, no. 1 (2014): 165-186. 
nya shame adalah emosi sosial; shame berhubungan dengan seluruh jati diri manusia, sementara guilt berbicara tentang perilaku terentu; shame berorientasi terhadap diri dan guilt terhadap orang lain. ${ }^{2}$ Georges menjelaskan tentang bagaimana budaya shame dan guilt memandang suatu perilaku itu pantas. Beliau mengatakan bahwa budaya shame akan menilai perilaku itu berdasarkan kacamata komunitas, berbeda dengan budaya guilt yang menilai ideal berdasarkan hukum dan peraturan. Budaya guilt mengandalkan internalisasi nilai ke dalam hati nurani, sementara budaya shame mengandalkan tekanan sosial dari luar diri untuk memastikan seseorang berlaku benar. ${ }^{3}$ Pandangan serupa juga didukung oleh Pakpahan yang menyatakan, bahwa dalam budaya shame budaya moral dimana seseorang dinilai oleh orang lain maka keputusan moral merupakan hasil dari tekanan sosial. ${ }^{4}$

Sangat menarik bahwa menurut George dalam budaya shame, komunitas lebih berperan besar dalam pembentukan nilai dibandingkan dengan budaya guilt yang lebih condong kepada internalisasi nilai secara individual. Bahkan dalam tulisannya bisa ditemukan bahwa cara masalah diselesaikan dalam budaya shame adalah restorasi honor/kehormatan bukan oleh diri sendiri lewat permintaan maaf tapi oleh pihak luar yaitu komunitas. Ini terjadi karena ketika pelanggaran terjadi pihak yang terpengaruh adalah komunitas bukan sekedar yang melanggar saja. ${ }^{5}$

Penelitian yang dilakukan oleh Pakpahan tentang shame dan guilt dalam budaya Indonesia membahas bagaimana pengaruh budaya shame dalam bahasa. Dalam bahasa Indonesia kata malu 'malu/shame' itu punya konteks relasional sementara kata 'salah/guilt' punya konteks hukum. Nilai shame dan guilt sangat berhubungan, namun dalam konteks nilai moral, shame lebih digunakan dibandingkan guilt. $^{6}$ Lebih lagi Pakpahan menjelaskan bahwa dalam bahasa daerah tertentu di Indonesia kata shame dan guilt tidak dipisahkan. Adapula bahasa daerah seperti bahasa jawa yang tidak memiliki kata untuk guilt sementara untuk shame ada dalam kosakatanya. ${ }^{7}$ Anak-anak dalam budaya jawa diajarkan untuk menunjukan hormat (wedi) pada orang tua dan untuk punya shame (isin) ketika ditegur di depan umum. Dalam bahasa Batak tidak ada kata guilt, yang dipakai adalah maila. Kata itu merujuk pada perasaan yang muncul ketika kesadaran akan shame muncul setelah membuat kesalahan. Maila bukan hanya datang dari hukuman orang lain namun karena adanya pelanggaran terhadap hukum.

\footnotetext{
${ }^{2}$ Binsar Jonathan Pakpahan, "Shameless and Guiltless: The Role of Two Emotions in the Context of the Absence of God in Public Practice in the Indonesian Context," Exchange 45, no. 1 (February 23, 2016): 1-20; Kurt April and Boipelo Mooketsi, "Dealing with Guilt and Shame after Breaking the Glass Ceiling: The Case of South African Executive Women," Effective Executive Journal 3, no. 8 (2010): 69-70.

${ }^{3}$ Jayson Georges and Mark D. Baker, Ministering in Honor-Shame Cultures: Biblical Foundations and Practical Essentials (Illinois: InterVarsity Press, 2016), 42.

${ }^{4}$ Pakpahan, "Shameless and Guiltless," 6.

${ }^{5}$ Georges and Baker, Ministering in Honor-Shame Cultures: Biblical Foundations and Practical Essentials, 46.

${ }^{6}$ Pakpahan, "Shameless and Guiltless," 8

${ }^{7}$ Pakpahan menjelaskan bahwa dalam bahasa Jawa, kata 'isin / lingsem', 'sungkan', dan 'wirang' merujuk pada shame, namun untuk kata guilt, mereka menggunakan bahasa Melayu, 'salah'.
} 
Shame merupakan lawan dari kata honor (hormat). Dan tujuan hidup dari orang batak adalah kehormatan, keturunan dan kekayaan. ${ }^{8}$

Terlihat di atas bahwa nampak tidak ada perbedaan tentang istilah malu/shame dan salah/guilt dalam budaya Indonesia. Bahkan kedua istilah tersebut dalam konteksnya memiliki arti yang lebih dekat dengan shame. Sehingga dapat terlihat bahwa dinamika worldview honor shame lebih terasa dalam budaya Indonesia. Di barat, topik mengenai budaya honor-shame, fear-power dan guilt-innosence banyak diperdebatkan dalam jurnaljurnal misiologi, diajarkan dalam konfrensi misi dan diperbincangkan dengan ringan di antara misionari dan keluarganya. ${ }^{9}$ Pembahasan tentang ketiga domain ini banyak teliti oleh sosiolog dan antropolog yang berargumen bahwa barat yang individualis, dan "Kristen" lebih condong kepada guilt/innocence; budaya kolektif condong ke honor/shame; sementara budaya animistik lebih condong kepada power/fear. ${ }^{10}$

Dalam penelitian yang dibuat oleh Whiteman, ia mengemukakan pentingnya memahami tipologi budaya ini untuk dapat membantu orang Kristen agar dapat bagaimana budaya dan worldview individu dapat membentuk cara individu melihat dan memahami Firman Tuhan. ${ }^{11}$ Hal ini punya implikasi bahwa seseorang dengan kecenderungan tertentu dalam hal budaya dan world view dari ketiga tipologi, dapat melewatkan konsep-konsep tertentu yang berada diluar perspektif budayanya. Meskipun topik budaya dan pengaruhnya cukup banyak dibahas dalam jurnal-jurnal di Barat, namun ini topik ini jarang dibahas di dalam lingkaran gereja dan misi di Indonesia. Pembahasan honor-shame dan implikasinya dalam gereja dan pelayanan kurang banyak dieksplore dan dibahas padahal jika dilihat dari jurnal-jurnal di barat, pengaruh dari budaya tersebut sangat penting bagi praktik pelayanan gereja lokal. Dalam suatu penelitian, Vries menemukan bahwa penjelasan Injil honor-shame lebih efektif dalam hal menjelaskan tentang konsep penebusan kepada orang muslim Arab. ${ }^{12}$ Penelitian ini dilatarbelakangi oleh kondisi kekristenan di Arab yang kurang bertumbuh dan diduga disebabkan oleh karena konsep penebusan yang dibawa misionari kurang bisa mengakomodasi budaya setempat, karena disampaikan dalam konteks budaya guilt. Mischke dalam sebuah artikel menuliskan mengenai bahaya honor-shame. Ia juga membahas tentang tantangan yang dapat menghambat perkembangan misi dengan adanya konsep budaya honorshame. ${ }^{13}$ Atas dasar itu maka rumusan penelitian ini adalah sebagai berikut: Apakah Gereja Kemah Injil Indonesia Jemaat Rehobot mencerminkan budaya honor shame? Tujuan dari

\footnotetext{
${ }^{8}$ Pakpahan, "Shameless and Guiltless," 8-9.

${ }^{9}$ Johannes Merz, "The Culture Problem: How the Honor/Shame Issue Got the Wrong End of the Anthropological Stick," Missiology: An International Review 48, no. 2 (2020): 127-141.

${ }^{10}$ Geoff Beech, "Shame/Honor, Guilt/Innocence, Fear/Power in Relationship Contexts:," International Bulletin of Mission Research (September 20, 2018): 334, accessed August 15, 2020, https://journals.sagepub.com/doi/10.1177/2396939318783682.

${ }^{11}$ Darrell Whiteman, "Shame/Honor, Guilt/Innocence, Fear/Power: A Missiological Response to Simon Cozens and Geoff Beech," International Bulletin of Mission Research 42, no. 4 (October 1, 2018): 355.

${ }^{12}$ Grant DeVries, "Explaining the Atonement to the Arabic Muslim in Terms of Honour and Shame: Potentials and Pitfalls," St Francis Magazine II, no. 4 (2007): 59.

${ }^{13}$ Werner Mischke, "Giving Honor: A Key to Fruitful Cross-Cultural Partnerships," Evangelical Missions Quarterly 54, no. 4 (2019): 7-10.
} 
penelitian ini adalah untuk mengetahui apakah Gereja Kemah Injil Indonesia Jemaat Rehobot mencerminkan budaya honor shame.

\section{Metode}

Penelitian ini menggunakan pendekatan ethnography, yang mencari gambaran tentang budaya atau kelompok orang dan gaya hidup, pemahaman dan kepercayaan yang mereka miliki. ${ }^{14}$ Penelitian ini bertumpu pada studi literatur yang relevan. Pembacaan dilakukan dengan penalaran induktif. Dengan penalaran induktif maka dalam pembahasan akan ditulis dalam dua langkah. Langkah pertama adalah penjelasan tentang fakta atau teori penelitian sebelumnya. Langkah kedua adalah deskripsi mengenai hasil temuan di lapangan. Proses ini diawali dengan pemaparan hasil studi literatur tentang fitur-fitur khusus yang terdapat dalam budaya honor shame. Kemudian tiap fitur yang ada akan dibandingkan dengan temuan di lapangan berdasarkan observasi dan wawancara sehingga dapat disimpulkan apakah konteks pelayanan di gereja yang diteliti mencerminkan budaya honor shame.

\section{Hasil dan Pembahasan}

Berikut ini akan dijabarkan dalam tulisan ini tentang enam fitur budaya yang biasanya muncul dalam budaya honor shame dan pembahasan bagaimana fitur tersebut dicerminkan dalam Gereja.

\section{Patronage}

Georges menjelaskan bahwa patronage berbicara tentang hubungan timbal balik antar dua pihak yang tidak seimbang. Jadi biasanya pihak yang "lebih tinggi" atau kaya membantu menyediakan sumber daya kebutuhan hidup dan keamanan kepada pihak yang lain, dan sebagai balasannya, pihak yang diberikan akan memberikan hormat, mengabdi, dan berterima kasih kepada pihak tersebut. ${ }^{15}$

Dalam observasi, fitur patronage ternyata muncul dikalangan gereja. Biasanya yang kaya yang akan di angkat ke dalam posisi-posisi terhormat. Ketika mereka memberikan bantuan atau dana maka pendeta dan pemimpin yang lain merasa berhutang budi atau hormat (mungkin istilah "hutang budi" punyai kaitan dengan dinamika honor shame yang sedang penulis bahas). Tidak jarang pula ditemukan bahwa mereka yang menjabat sebagai bendahara gereja, bukanlah mereka yang terkenal dan punya reputasi dalam mengelola keuangan, melain kan mereka yang secara keuangan lebih tinggi dari anggota jemaat yang lain. Patron dalam gereja akan sering diberikan proposal untuk segala kebutuhan gereja, dan sebagai balasannya, mereka akan mendapatkan pujian atau pengakuan secara publik dalam pengumuman ibadah. Hasil wawancara menunjukan bahwa narasumber setuju dengan pengamatan ini. Itulah sebab

\footnotetext{
${ }^{14}$ Martyn Denscombe, The Good Research Guide: For Small-Scale Social Research Projects: For Small-Scale Social Research Projects, 4 edition. (Maidenhead: Open University Press, 2010), 79.

${ }^{15}$ Georges and Baker, Ministering in Honor-Shame Cultures: Biblical Foundations and Practical Essentials, 61.
} 
nya beliau merasa bahwa sangat penting bahwa pola ini perlu dihentikan dengan menegakan aturan yang ketat dalam pergantian pengurus.

\section{Indirect Communication}

Seringkali dalam budaya honor shame, orang-orang berkomunikasi dengan tujuan menjaga hubungan, identitas sosial dan bukan secara terang-terangan menyampaikan informasi. Menurut Georges "kebenaran" dalam komunikasi budaya honor shame harus dimakna kan secara hubungan antar personal bukan secara logis. Karena salah satu tujuan utama dari budaya honor shame adalah keharmonisan dalam komunitas jadi menghormati orang lain dan jaga image lebih penting sehingga menjadi "kebenaran" versi budaya honor shame. Dalam penerapannya seringkali individu yang "terlalu jujur" dan "blak-blakan" akan beresiko melukai orang lain. Oleh sebab itu komunikasi tidak langsung (indirect) menjadi suatu strategi untuk mengurangi shame/malu. ${ }^{16}$

Melalui studi literatur yang dibuat mengenai topik ini, didapatkan insight baru mengenai kesenjangan hubungan yang terjadi antara penulis dan para pemimpin lain di gereja. Ada beberapa kejadian mengenai isu komunikasi tidak langsung yang sangat mengena gambarannya dengan teori yang dipaparkan di atas. Observasi dalam rapat ketika penulis sedang menyampaikan pendapat, dan secara langsung memberikan argumen tentang pendapat yang diberikan pemimpin lain, penulis dianggap sebagai orang yang tidak sopan dan tidak menghargai. Di sisi lain penulis menganggap bahwa pemimpin lain tidak punya keberanian untuk menuntaskan perbincangan ketika terjadi perbedaan pendapat didalamnya. Hampir setiap kali perbedaan pendapat atau argumen terjadi maka akan diakhiri dengan pihak pemimpin lain merasa dipermalukan, sehingga perbincangan diakhiri dengan kurang harmonis.

Dalam kasus lain, sulit sekali dalam rapat Badan Pengurus Jemaat apabila terjadi suatu sanggahan dari seseorang yang ada dalam ruang rapat, atau dari orang luar bahwa sanggahan tersebut dibahas secara langsung. Artinya, seringkali sumber sanggahan, dan kepada siapa sanggahan itu diberikan tidak secara lugas dinyatakan. Jadi dari pada mengatakan, secara pribadi, atau menyebut nama orang lain, biasanya kata yang digunakan adalah, "ada yang bilang..." Waktu ditanyakan siapa orangnya, jarang ada yang mau memberikan penjelasan. Narasumber mengakui bahwa dalam bergereja, keharmonisan lebih dijunjung tinggi ketika berusaha untuk meyampaikan kebenaran. Bahkan dinyatakan bahwa jika tidak berhati-hati dalam menyampaikan kebenaran, justru akan dapat menjadi bumerang bagi diri sendiri.

\section{Event Focus}

Menurut Georges budaya honor shame sangat mementingkan komunitas bukan sekedar penyelesaian suatu acara. Untuk itu dalam budaya honor shame yang paling penting adalah ketika orang sudah hadir daripada menjalankan suatu kegiatan sesuai dengan waktu yang dijadwalkan. Tepat waktu adalah ketika semua atau kebanyakan orang sudah hadir di

\footnotetext{
${ }^{16}$ Ibid., 63-67.
} 
acaranya, bukan ketika waktu dimulai sesuai dengan rencana yang sudah ditetapkan untuk acaranya. ${ }^{17}$ Teori ini menjelaskan mengapa seringkali berdasarkan observasi ibadah-ibadah di Gereja Kemah Injil Indonesia tidak dimulai tepat waktu. Keterlambatan bisa diterima selama jemaat kebanyakan sudah datang. Bukan hanya ibadah, biasanya acara pernikahan, rapat, dan lain-lain juga seperti ini. Seandainya pun tepat waktu, biasanya waktunya sangat mepet dengan waktu yang dijadwalkan atau telah diumumkan. Seringkali inilah yang disebut di Indonesia sebagai 'jam karet'. Karena budaya 'jam karet' itulah makanya sejak awal sebagai gembala, narasumber berusaha untuk mendidik jemaat untuk tepat waktu berlawanan dengan budaya umumnya. Sehingga bisa dikatakan pada bagian ini di Gereja Kemah Injil Indonesia Jemaat Rehobot Taman Wisma Asri fitur event focus ini dengan sengaja diubah sehingga acara akan dimulai tepat waktu tanpa memusingkan banyak sedikitnya tamu.

\section{Purity}

Lawan kata dari kata suci adalah najis. Dalam budaya honor shame, kesucian merupakan salah satu fitur penting dalam budaya ini karena kesucian dan kenajisan adalah suatu sumber dari kehormatan dan malu. Selanjutnya Georges menjelaskan bahwa konsep ini bukan hanya berbicara mengenai hal-hal yang menajiskan kesucian secara fisik namun juga mengenai kesucian pribadi dan sosial. ${ }^{18}$ Dalam hal ini sangatlah wajar untuk dipahami pembaca mengapa di Indonesia dengan angka penduduk muslim terbesar di satu negara, sertifikasi halal begitu menjadi hal yang besar. Sertifikasi halal menjadi suatu jaminan bagi masyarakat bahwa produk yang dibeli sudah diawasi dengan seksama dan dijamin tidak mengandung hal-hal yang dapat menajiskan.

Fitur kesucian ini juga menjadi suatu fenomena yang besar di Gereja Kemah Injil Indonesia. ${ }^{19}$ Narasumber yang merupakan generasi kedua dari pendeta Gereja Kemah Injil Indonesia Jemaat Rehobot Taman Wisma Asri menjelaskan bahwa pada masa lalu berdansa, pergi ke bioskop, meminum kopi merupakan hal yang dianggap tabu atau dosa dalam budaya Kristen awal di Indonesia. Orang-orang yang bergereja tidak akan berani melakukan hal itu. Mungkinkah hal ini terjadi karena sebelumnya konsep kesucian dan najis sudah ada dalam nilai budaya sebelum masuknya kekristenan, sehingga ketika Kristen masuk maka nilainya tidak hilang namun bentuknya yang berubah?

Ada juga praktik-praktik tertentu yang sepertinya ritual yang merefleksikan fitur kesucian yang masih dilakukan sampai sekarang seperti di salah satu gereja di Alor dimana setiap Minggu, semua jemaat yang ikut beribadah dengan pakaian putih, orang yang ketahuan berdosa (berzinah) harus duduk di luar gedung sampai masa tertentu sebagai bentuk disiplin gereja. Setiap perempuan harus memakai rok dimana saja, karena celana panjang yang dianggap sebagai bukan pakaian wanita (tafsiran akan hukum Allah dalam Perjanjian Lama) dan ini merupakan kekejian bagi Allah. Apabila perempuan yang kedapatan mengenakan

\footnotetext{
${ }^{17}$ Ibid., 67-68.

${ }^{18}$ Ibid., 68-69.

${ }^{19}$ Albert Benjamin Simpson, Injil Empat Berganda (Bandung: Kalam Hidup, 2012).
} 
celana, maka akan dikenakan sanksi disiplin sebagai bentuk dari menjaga kesucian dalam jemaat.

\section{Social Roles}

Dalam budaya honor shame komunitas memberikan suatu peran khusus bagi tiap orang. Ada peranan yang diberikan berdasarkan jenis kelamin, usia, status sosial, kemampuan finansial, dan lain-lain. Seseorang yang bertingkah laku memenuhi eskpektasi sosial akan mendapatkan hormat. Hal ini termasuk di dalamnya cara berpakaian, cara berbicara, teman bergaul, pasangan yang dipilih. ${ }^{20}$ Narasumber setuju bahwa hal ini terlihat jelas dalam kegiatan bergereja. Beliau mengatakan bahwa ada ekspektasi dalam hal berpakaian bagi para pemimpin gereja dan pengkhotbah yang memakai kemeja, dasi dan jas. Jika tidak lengkap maka dianggap tidak mengetahui sopan santun.

Dari observasi penulis juga mengamati bahwa ekspektasi-ekspektasi tertentu yang lebih banyak dari cara berpakaian juga banyak diterapkan kepada para pemimpin gereja dan keluarganya. Ekspektasi tentang bersikap, pengetahuan tentang firman Tuhan, kesempurnaan dalam keluarga, dan lain-lain. Seringkali hal inilah yang membuat takut anggota keluarga jika salah satu anggotanya dicalonkan untuk menjadi pemimpin gereja. Topeng sosial bisa men jadi salah satu jalan keluar dalam budaya ini berdasarkan observasi. Dengan topeng sosial, individu dapat menyembunyikan pelanggaran dan tetap menampilkan pribadi yang sesuai dengan ekspektasi ketika berada bersama masyarakat.

\section{Hospitality}

Hospitality adalah kesempatan untuk mendapatkan kehormatan lewat jamuan. Seringkali pesta adalah suatu cara untuk menunjukkan status. Kegagalan untuk bisa menjamu tamu dengan baik akan mengakibatkan malu. Hospitality juga dapat digunakan untuk mengundang seorang asing menjadi teman. Ini berarti bahwa bukan saja hospitality bisa mengangkat status dari yang menjamu tapi juga yang dijamu. Menurut George, perilaku hospitality seringkali dianggap sebagai perilaku pamer yang sia-sia (ostentation) dan juga suatu kewajiban yang dilakukan karena takut diancam oleh gosip. ${ }^{21}$

Observasi berikutnya adalah tentang salah satu kebiasaan gereja yang menyediakan makanan untuk jemaat pada event-event tertentu. Meski biaya makanan adalah salah satu yang terbesar dalam budget tapi itu dianggap penting. Menurut narasumber, mereka berusaha untuk menjalankan tanggungjawab hospitality untuk menyenangkan tamu-tamunya. Pandangan yang terlalu pragmatis dalam melihat budaya hormat honor shame gereja justru akan menimbulkan kesan bahwa gereja sedang membuang-buang uang hanya untuk tradisi “makan-makan". Penulis tidak pernah mengidentifikasikan nilai hospitality sebagai satu nilai

\footnotetext{
${ }^{20}$ Georges and Baker, Ministering in Honor-Shame Cultures: Biblical Foundations and Practical Essentials, 70-72.

${ }^{21}$ Ibid., 72-73.
} 
yang penting dalam budaya Indonesia dan juga budaya gereja. Hal ini membuat terjadinya clash budaya yang membuat penulis memiliki prejudice terhadap perilaku tersebut.

\section{Implikasi}

Berdasarkan hasil dari penelitian ini maka didapatkan beberapa implikasi penting yang bisa diterapkan dalam pealayanan: Pertama, budaya honor shame membuat dinamika pemuridan berbeda dengan yang diajarkan oleh buku-buku dari barat, karena itu perlu ada kontekstualisasi tentang pemuridan bagi budaya honor shame. Hal ini penting mengingat internalisasi nilai dalam budaya honor shame yang komunal merupakan sesuatu tantangan dibanding pada budaya barat; Kedua, nilai-nilai dalam budaya honor shame dan guilt innocence perlu diajarkan secara detil sesuai dengan konteksnya masing-masing agar bisa mencegah prejudice dan misjudgement oleh pihak-pihak yang memiliki budaya yang berbeda. Hal ini haruslah menjadi kurikulum pengajaran warga jemaat mengingat dengan masuknya budaya global lewat kemajuan tekonlogi yang tanpa disadari bisa memasukkan pula nilai-nilai budaya guilt ke generasi muda. Ini dapat menimbulkan gap budaya. Hal ini penting agar setiap orang dapat menelaah budaya bukan sekedar dari perilakunya, namun dari framework mengapa perilaku itu muncul, dan pemahaman ini dapat menjembatani suatu komunikasi antar generasi yang sudah dipengaruhi budaya guilt. Ketiga, dalam kerjasama yang melibatkan pihak-pihak yang mempunyai budaya yang berbeda perlu dikembangkannya teknik komunikasi yang lebih mendalam. Teknik komunikasi perlu dikembangkan agar faktor budaya yang bisa menjadi noise antara komunikator ke komunikan bisa diperkecil bahkan dihilangkan. Di sisi lain perlu diperhatikan bahwa asumsi-asumsi yang kita miliki terhadap orang yang memiliki budaya lain perlu disampaikan dan diuji kebenarnnya dengan cara yang ramah saat berkomunikasi. Ini penting bagi orang yang memeluk budaya honor shame karena adanya fitur indirect communication; Keempat, pendidikan nilai kepada anak perlu juga di perhatikan secara khusus. Bagi budaya honor shame, mengajarkan nilai karena alasan tuntutan komunitas tidak akan bisa untuk membuat anak menginternalisasi nilai secara maksimum. Bagian ini hampir serupa dengan poin pertama; Kelima, dalam melayani di budaya honor shame, perlu dipahami bahwa adanya tuntutan untuk berperilaku oleh lingkungan, Untuk itu penting sekali untuk memahami peraturan-peraturan tidak tertulis yang dipegang oleh lingkungan supaya pelayanan yang dibuat tidak ditolak oleh lingkungan; Keenam, karena sebagian besar buku mengenai teologi diwarnai oleh para pemikir barat, perlu dipikirkan juga bagaiman cerita-cerita Alkitab dan Injil disesuaikan agar lebih sesuai dengan konteks budaya honor shame. Hal ini akan lebih cocok untuk melayani mereka yang berlatar belakang non Kristen di Indonesia. Kelebihan lain dari kisah Alkitab dan Injil yang dikontekstualisasikan adalah bahwa nilai-nilai yang diajarkan akan lebih menyentuh kepada hati yang sudah terbiasa selaras dengan budaya honor shame. 


\section{Kesimpulan}

Dari informasi yang dikumpulkan, dapat disimpulkan bahwa budaya Gereja Kemah Injil Indonesia jemaat Rehobot Taman Wisma Asri sangat mencerminkan gaya hidup, pemahaman dan kepercayaan yang dimiliki oleh budaya honor shame. Hal ini merupakan pengetahuan yang sangat berguna secara praktis bagi pembaca karena lewat tulisan ini, pembaca dapat lebih dapat berhati-hati untuk memberikan label kepada orang-orang yang ada dalam budaya honor shame. Lewat studi ini juga ditemukan pencerahan mengenai beberapa kejadian yang merujuk kepada clash budaya dalam pelayanan.

\section{Rujukan}

April, Kurt, and Boipelo Mooketsi. "Dealing with Guilt and Shame after Breaking the Glass Ceiling: The Case of South African Executive Women." Effective Executive Journal 3, no. 8 (2010): 69-70.

Beech, Geoff. "Shame/Honor, Guilt/Innocence, Fear/Power in Relationship Contexts:" International Bulletin of Mission Research (September 20, 2018). Accessed August 15, 2020. https://journals.sagepub.com/doi/10.1177/2396939318783682.

Denscombe, Martyn. The Good Research Guide: For Small-Scale Social Research Projects: For Small-Scale Social Research Projects. 4 edition. Maidenhead: Open University Press, 2010.

DeVries, Grant. "Explaining the Atonement to the Arabic Muslim in Terms of Honour and Shame: Potentials and Pitfalls." St Francis Magazine II, no. 4 (2007).

Georges, Jayson, and Mark D. Baker. Ministering in Honor-Shame Cultures: Biblical Foundations and Practical Essentials. Illinois: InterVarsity Press, 2016.

James, Aleya, and Candy McLeod. "An Analysis of the Three Colors Worldview Mapping Tool: Contrasting Emirati and Non-Emirati Worldviews.” Intercultural Communication Studies XXIII, no. 1 (2014): 165-186.

Merz, Johannes. "The Culture Problem: How the Honor/Shame Issue Got the Wrong End of the Anthropological Stick." Missiology: An International Review 48, no. 2 (2020): 127-141.

Mischke, Werner. "Giving Honor: A Key to Fruitful Cross-Cultural Partnerships." Evangelical Missions Quarterly 54, no. 4 (2019): 7-10.

Muller, Roland. Honor and Shame: Unlocking the Door. 1st edition. Philadelphia, Pa.: Xlibris, 2001.

Pakpahan, Binsar Jonathan. "Shameless and Guiltless: The Role of Two Emotions in the Context of the Absence of God in Public Practice in the Indonesian Context." Exchange 45, no. 1 (February 23, 2016): 1-20.

Simpson, Albert Benjamin. Injil Empat Berganda. Bandung: Kalam Hidup, 2012.

Whiteman, Darrell. "Shame/Honor, Guilt/Innocence, Fear/Power: A Missiological Response to Simon Cozens and Geoff Beech." International Bulletin of Mission Research 42, no. 4 (October 1, 2018): 348-356. 